\title{
The Effectiveness of Cooperative Learning Method (Student Team Achievement Divisions) in Christian Education
}

\author{
Sandy Ariawan \\ Christian Education, STIPAK Malang, Indonesia \\ ariawan.sandy@yahoo.com
}

\section{Keywords: \\ Cooperative learning, Inquiry learning, Christian education,}

\begin{abstract}
ABSTRAK
This study aimed to evaluate the use of cooperative learning method (Student Team Achievement Division) in character subject in Christian Education among State Vocational High School 8 Malang. A total of 26 students were involved in the study, separated in two classes. The first class was treated with Cooperative Learning Method and the other class as a control class. Student achievement was measured based on the pre-test and post-test. The result obtained from this study, using quasiexperimental design with paired sample T-test, sig. $(0,002)<0,05$, indicated that the Cooperative Learning Method is effective in Christian education. From the finding of this study, it is recommended cooperative learning method as one of the appropriate method and practices in character building for Christian Education.
\end{abstract}

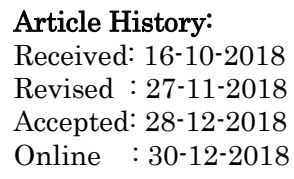

\section{A. INTRODUCTION}

It is really embarrassing that United Nations of Educational, Scientific and Cultural Organization (UNESCO) survey in 2016 reported that Indonesia teacher's quality was in $14^{\text {th }}$ position of 14 Asia Pacific developing countries. One factor of the low quality of education in Indonesia is because of the weakness of the teacher's role in exploring the students' potential without ever noticing the needs, interests, and talents that their students have.

The effectiveness and efficiency of learning in school depend heavily on the teacher's role. In this case, there are a number of roles carried by the teacher. Syamsuddin (A, Syamsudin, 2003) suggests that in the broad sense of education, an ideal teacher should be able to act as a conservator, transmitter, transformer, and as an organizer. Teachers as a party directly involved with the students in the learning process, of course, have a very central and strategic position. Teachers are required to be able to understand both learning and personal materials and students' character in learning. Teachers as the learning process executor can find a variety of approaches, strategies, methods and techniques that are appropriately used and considered effective in achieving educational objectives that can then be applied in curriculum and teaching planning. 
According to Slavin (Robert E. Slavin et al., 2003), Cooperative Method - STAD is a learning model that emphasizes on cooperation and group responsibilities. Knowledge is formed and built through cooperation in learning activities, including investigating, discussing, understanding, and solving problems. Students work in groups cooperatively to complete their learning materials. Heterogeneous groups formed consisting of high, moderate and low-level students, genders vary, and awards given are more group-oriented than individuals. According to Anita Lie (Anita, 2004), "Cooperative learning contains understanding as a common attitude or behaviour in work or assisting among others in a regular cooperative structure in a group, consisting of two or more people in which success of work is heavily influenced by the involvement of each member of the group." From the notion that the above experts can be concluded that cooperative learning is a process of briefing and mentoring by teachers to students to gain understanding of the material being taught by emphasizing the process of cooperation among students.

Cooperative learning is identical to cooperation in the Learning Group. Cooperation between students is certainly in the positive with the guidance of teachers to achieve the purpose of learning. Students in the cooperative learning model are expected to help each other to achieve an understanding of the learning materials. By interacting, they will gain knowledge.

The basis of the theory behind a cooperative according to Slavin (R. E. Slavin, 2010) is cognitive that emphasizes on the influence of cooperation itself. According to him, cooperative learning arises and is born of human nature as a social creature. People interact with each other to develop knowledge. Interactions in cooperative learning are embodied in groups. The group can consist of two or more students.

Cooperative learning in the practice of a teacher needs to pay attention to some basic principles for the implementation of learning. The principles expressed by Stahl in Solihatin (Etin Solihatin dan Raharjo, 2012) are: the formulation of a clear study purpose, a thorough acceptance by students about the purpose of learning, the positive dependence, an open interaction, individual responsibility, the heterogeneous groups, the interaction of positive attitudes and social behaviour, follow-up, and learning satisfaction.

Cooperative learning will be carried out well when all the basic concepts above can be fulfilled in the learning process, because all nine concepts cannot be separated or reduced in application. When one is not implemented, it will reduce the effectiveness and productivity of the model which will also affect student learning outcomes.

In addition to the principle, in cooperative learning there are also some elements. Roger and David Johnson in Anita Lie (Anita, 2004) mention that there are five elements of cooperative learning as follows: 1 . Positive inter dependence; 2 . Personal responsibility; 3 . Face to face promotive-interactive; 4. Inter personal skills; 5. Group processing. Referring to the five elements above indicates that the group cooperation in cooperative learning is not merely cooperation can be between two or more students. The so-called group cooperation in cooperative learning is the cooperation in which inter-group members are dependent on each other. Each group has a responsibility to achieve success. Therefore, in such a study group must occur mutual help among members, exchange information, remind each other and motivate, mutual trust, and jointly process the information. Essentially in a cooperative learning group there must be an effective and efficient interaction in the study group.

Cooperative learning is used in the field of education because it has advantages. The advantages of cooperative learning are: A) Improve student learning outcomes, B) Develop relationships between groups, C) increase self-esteem, d) raise students' awareness to receive a 
weak classmate, E) Foster students' awareness to think and apply their knowledge (R. E. Slavin, 2010).

Some of the components in the cooperative learning of STAD are as follows: First, Preparation Stage; Before presenting the material, the teacher emphasized the significance of the group's assignments and to motivate the students' curiosity about the concepts to be learned, then explain the material to be learned today. Thus students are clear and understand what materials will be discussed.

Second, Group Activity Stage; During group activities, teachers act as facilitators and monitor each group's activities. Students perform assignments independently or in pairs, then match each other's answers and check the accuracy of the answers with a group friend. If a member is lacking in understanding then his/her group of friends is responsible for explaining before asking to the teacher.

Third, Class Presentation; In this activity, students present all the results of their discussions, while the other group pays attention to what is presenting in front. The other group is tasked with responding and questions when there are not yet understood. Teachers only become facilitators when there is difficulty and the teacher will explain.

Fourth, Quiz Stage and Evaluation; After the group presentation, followed by the quiz. The quiz is later done by each group as quickly and precisely as possible. Students are conditioned to return to sit according to the initial seat. Every end of learning a subject is evaluated to know the level of understanding and progress of individual learning. Students are given questions or problems to work with individually, and students are individually responsible for working on the test material.

Fifth, Make a Conclusion; After performing the quiz, students are assisted by the teacher together taking conclusions from the learning process. And Sixth, Group Award Stage; After the calculation of individual developmental values, the subsequent recognition is given as a form of appreciation to the group that successfully achieved certain criteria. The way to determine the group score is to collect the scores of each group member, then sum and averaged. The results were used as group progress (Zubaidah, 2010).

The STAD Model demands students to help one another, motivate, and trust each other. They work together and help each other make the group the best, where in the STAD model for the best group will be rewarded. Rewards or awards are a motivator for students to make the group the best in the class. This condition will create a healthy competitive atmosphere among students. They must give the spirit of his teammates to do their best, giving the spirit that learning is important, helpful and enjoyable. They can work in pairs by comparing the answers, discussing the differences, and helping each other face a dead end. The approach used to solve the problem, or they can give one another quiz about the material learned. They teach their teammates and access their strengths and weaknesses to help them succeed in the quiz.

Although the students in the team always work together, but when the quiz they have to work on their own without helping each other anymore. This condition will bring out the nature of individual responsibilities in students. Students will strive to become tutors for other students in one group to achieve their goals as the best group in the class (Muldayanti, 2013). The STAD learning model puts the student's position as the subject of his studies. Such learning is able to develop the potential that is embedded within it. The student's position of the subject in learning will make students more active. The active process in this question and argument gives students the opportunity to express themselves and foster critical thinking in students. In addition, students are also given the opportunity to find something in the learning process. 
Students as a centre in the learning process allow students to generate new solutions for a problem given by the teacher. Self-expression, critical thinking and discovery by students will certainly foster creativity in students (Ariawan, 2018). This kind of learning will not put pressure on the student, but will make the students quieter, thus undergoing a sincere learning process. In simple learning models STAD can be attributed in a learning model that is in accordance with the principles of PAKEM (active learning, creative, and fun). PAKEM is a pattern that is oriented towards the establishment of self-reliance thinking and to hone creativity. The implementation is directed at all subjects given at school (Kunandar, 2007).

According to Soewarso (Soewarso, 1998), the advantages of the STAD model are as follows: a. Help students learn the content of the subject matter being discussed; $b$. The presence of other group members who avoid the possibility of students getting low grades, because in the provision of oral tests the students are assisted by members of the group; c. Make students able to learn to argue, learn to listen to others' opinions and record things that are beneficial for common interest; $d$. To produce high student learning and increase student self-esteem and improve relations with peers; e. Prizes or awards given will provide encouragement or students to achieve higher outcomes; f. Students who are slow thinking can be assisted to add science; g. The formation of small groups makes it easy for teachers to monitor their students in working together.

This study aimed to evaluate the effectiveness of cooperative learning method (Student Team Achievement Division) in character subject in Christian Education among State Vocational High School 8 Malang

\section{B. METHODS}

This study is a quantitative research, using quasi-experimental design with paired sample Ttest (Sugiyono, 2017). Respondents are high school students of State Vocational 8 Malang. All respondents are separated into 2 different classes. One class will get treatment in the form of cooperative learning method, while the other class does not get treatment and serves as a control class. Then, to both classes will be given pre-tests and post-test which will be tested with normality test as condition to be done paired sample T-Test.

\section{RESULT AND DISCUSSION}

\section{Test of Normality}

Table 1. Tests of Normality

\begin{tabular}{|l|r|r|r|r|r|r|}
\hline & \multicolumn{4}{|c|}{ Kolmogorov-Smirnova } & \multicolumn{3}{c|}{ Shapiro-Wilk } \\
\cline { 2 - 7 } & Statistic & \multicolumn{1}{c|}{ Df } & \multicolumn{1}{c|}{ Sig. } & Statistic & \multicolumn{1}{c|}{ df } & \multicolumn{1}{c|}{ Sig. } \\
\hline PreTest & .211 & 13 & .116 & .930 & 13 & .345 \\
PostTest & .184 & 13 & $.200^{*}$ & .895 & 13 & .114 \\
\hline
\end{tabular}

*. This is a lower bound of the true significance.

a. Lilliefors Significance Correction

In test of normality with Shapiro-Wilk, it appears that the number of significance for pre-tests and post-test is entirely above 0,05. This means that the distributed data is normal and is eligible for a test Paired Sample T-Test. 


\section{Paired Sample T-test}

Table 2. Paired Samples Statistics

\begin{tabular}{|rl|r|r|r|r|}
\hline & & Mean & N & Std. Deviation & \multicolumn{1}{c|}{ Std. Error Mean } \\
\hline \multirow{2}{*}{ Pair 1 } & PreTest & 54.62 & 13 & 10.300 & 2.857 \\
& PostTest & 67.69 & 13 & 10.727 & 2.975 \\
\hline
\end{tabular}

In the Table 2 above it appears that the average value for pre-tests is 54,62 . While the average value of post-test is 67,69 .

Table 3. Paired Samples Correlations

\begin{tabular}{|lc|r|r|r|}
\hline & N & Correlation & \multicolumn{1}{c|}{ Sig. } \\
\hline Pair 1 & PreTest \& PostTest & 13 & .350 & .242 \\
\hline
\end{tabular}

In the Table 3 above, it appears that the correlation coefficient is 0,350 with significance of 0,242 . Because of the significance value $(0,242)>$ probability $(0,05)$ then it can be said that there is no correlation between the pre-tests and post-test variables.

Table 4. Paired Samples Test

\begin{tabular}{|c|c|c|c|c|c|c|c|c|c|}
\hline & & \multicolumn{5}{|c|}{ Paired Differences } & \multirow[t]{3}{*}{$\mathrm{t}$} & \multirow[t]{3}{*}{ df } & \multirow{3}{*}{$\begin{array}{l}\text { Sig. (2- } \\
\text { tailed) }\end{array}$} \\
\hline & & \multirow[t]{2}{*}{ Mean } & \multirow[t]{2}{*}{$\begin{array}{c}\text { Std. } \\
\text { Deviatio } \\
\mathrm{n}\end{array}$} & \multirow[t]{2}{*}{$\begin{array}{l}\text { Std. } \\
\text { Error } \\
\text { Mean }\end{array}$} & \multicolumn{2}{|c|}{$\begin{array}{l}95 \% \text { Confidence } \\
\text { Interval of the } \\
\text { Difference }\end{array}$} & & & \\
\hline & & & & & Lower & Upper & & & \\
\hline $\begin{array}{l}\text { Pair } \\
1\end{array}$ & $\begin{array}{l}\text { PreTest } \\
\text { - } \\
\text { PostTest }\end{array}$ & 13.077 & 11.996 & 3.327 & -20.326 & -5.828 & -3.930 & 12 & .002 \\
\hline
\end{tabular}

The above Table 4 can be noted that the value of Sig. (2-tailed) is $0,002<0,05$. This indicates that there is a significant average difference between pre-tests and post-test results, which means the use of cooperative learning methods in Christian education is proven effective.

Table 5. Paired Samples Test of Class Control

\begin{tabular}{|c|c|c|c|c|c|c|c|c|c|}
\hline & & \multicolumn{5}{|c|}{ Paired Differences } & \multirow[t]{3}{*}{$\mathrm{t}$} & \multirow[t]{3}{*}{$\mathrm{df}$} & \multirow{3}{*}{$\begin{array}{l}\text { Sig. (2- } \\
\text { tailed) }\end{array}$} \\
\hline & & \multirow[t]{2}{*}{ Mean } & \multirow[t]{2}{*}{$\begin{array}{c}\text { Std. } \\
\text { Deviatio } \\
\text { n }\end{array}$} & \multirow[t]{2}{*}{$\begin{array}{l}\text { Std. } \\
\text { Error } \\
\text { Mean }\end{array}$} & \multicolumn{2}{|c|}{$\begin{array}{c}95 \% \\
\text { Confidence } \\
\text { Interval of the } \\
\text { Difference } \\
\end{array}$} & & & \\
\hline & & & & & Lower & Upper & & & \\
\hline $\begin{array}{l}\text { Pair } \\
1\end{array}$ & $\begin{array}{l}\text { PreTest } \\
\text { - } \\
\text { PostTest }\end{array}$ & -4.615 & 12.326 & 3.419 & -12.064 & 2.833 & -1.350 & 12 & .202 \\
\hline
\end{tabular}


Different results are shown in the control class. Number of significance indicates the number $0,202>$ probability 0,05 . This indicates that there is no significant average difference between pre-tests and post-test in the control class which does not get treatment.

\section{CONCLUSION AND SUGGESTIONS}

Based on the results of the study and the discussion, the conclusion that cooperative learning method (Student Teams Achievement Division-STAD) is effective in Christian education. From the finding of this study, it is recommended cooperative learning method as one of the appropriate method and practices in character building for Christian education.

\section{ACKNOWLEDGEMENT}

Gratitude for the help of the pricipal of State Vocational High School 8 Malang and all parties involved.

\section{REFERENCES}

A, Syamsudin, M. (2003). Psikologi kependidikan. In Psikologi Kependidikan. https://doi.org/10.1109/CCA.2000.897431

Anita, L. (2004). Cooperative Learning: Mempraktikkan Cooperative Learning di Ruang-Ruang Kelas. Jakarta: PT. Gransindo.

Ariawan, S. (2018). Pengaruh Apresiasi Gereja Berbentuk Materi dan Non Materi. Didaktikos Jurnal Pendidikan Agama Kristen Duta Harapan, 1(1), 8-16.

Etin Solihatin dan Raharjo. (2012). Penerapan Metode Pembelajaran Kooperatif Tipe Team. Bumi Aksara.

Kunandar. (2007). Guru Profesional Implementasi KTSP. Pustaka Pelajar.

Muldayanti, N. D. (2013). Pembelajaran biologi model stad dan TGT ditinjau dari keingintahuan dan minat belajar siswa. Jurnal Pendidikan IPA Indonesia, 2(1), 12-17. https://doi.org/10.15294/jpii.v2i1.2504

Slavin, R. E. (2010). Cooperative learning. In International Encyclopedia of Education (pp. 177-183). https://doi.org/10.1016/B978-0-08-044894-7.00494-2

Slavin, R. E., Hurley, E. A., \& Chamberlain, A. (2003). Cooperative Learning and Achievement: Theory and Research. In Handbook of Psychology. https://doi.org/10.1002/0471264385.wei0709

Soewarso. (1998). Menggunakan Strategi Kooperatif Learningdi Dalam Pendidikan Ilmu Pengetahuan Sosial. Rajawali Press.

Sugiyono. (2017). Sugiyono, Metode Penelitian. Penelitian, 34-45. https://doi.org/10.1021/ol7029646

Zubaidah, S. (2010). Pembelajaran Kolaboratif Dan Group Investigation (Sebagai Salah Satu Teknik Pembelajaran Kolaboratif). Makalah Pada Seminar Nasional Pembelajaran Biologi Dengan Tema, June, $1-22$.

https://www.researchgate.net/publication/318040393_PEMBELAJARAN_KOLABORATIF_DAN_GRO UP_INVESTIGATION_Sebagai_Salah_Satu_Teknik_Pembelajaran_Kolaboratif 